\title{
Evaluation of satellite rainfall estimates over Ethiopian river basins
}

\author{
T. G. Romilly and M. Gebremichael \\ Civil \& Environmental Engineering, University of Connecticut, CT, USA
}

Received: 25 August 2010 - Published in Hydrol. Earth Syst. Sci. Discuss.: 5 October 2010

Revised: 28 March 2011 - Accepted: 9 May 2011 - Published: 19 May 2011

\begin{abstract}
High resolution satellite-based rainfall estimates (SREs) have enormous potential for use in hydrological applications, particularly in the developing world as an alternative to conventional rain gauges which are typically sparse. In this study, three SREs have been evaluated against collocated rain gauge measurements in Ethiopia across six river basins that represent different rainfall regimes and topography. The comparison is made using five-year (2003-2007) averages, and results are stratified by river basin, elevation and season. The SREs considered are: the Climate Prediction Center morphing method (CMORPH), Precipitation Estimation from Remotely Sensed Information Using Neural Networks (PERSIANN) and the real-time version of the Tropical Rainfall Measuring Mission (TRMM) Multisatellite Precipitation Analysis (TMPA) 3B42RT. Overall, the microwavebased products TMPA 3B42RT and CMORPH outperform the infrared-based product PERSIANN: PERSIANN tends to underestimate rainfall by $43 \%$, while CMORPH tends to underestimate by $11 \%$ and TMPA 3B42RT tends to overestimate by $5 \%$. The bias in the satellite rainfall estimates depends on the rainfall regime, and, in some regimes, the elevation. In the northwest region, which is characterized mainly by highland topography, a humid climate and a strong Intertropical Convergence Zone (ITCZ) effect, elevation has a strong influence on the accuracy of the SREs: TMPA 3B42RT and CMORPH tend to overestimate at low elevations but give reasonably accurate results at high elevations, whereas PERSIANN gives reasonably accurate values at low elevations but underestimates at high elevations. In the southeast region, which is characterized mainly by lowland topography, a semi-arid climate and southerly winds, elevation does not have a significant influence on the accuracy of the SREs, and all the SREs underestimate rainfall across almost all elevations.
\end{abstract}

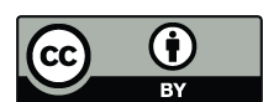

Correspondence to: $\mathrm{M}$. Gebremichael (mekonnen@engr.uconn.edu)

\section{Introduction}

High resolution satellite-based rainfall estimates (SREs) provide an alternative source of rainfall data for hydrological applications especially in developing countries, where conventional rain gauges are sparse. The near-real-time availability of the SREs makes them suitable for water resource management applications, however, an over or underestimation in the actual rainfall amount could lead to analysis results that give a false sense of security or a higher false alarm rate.

Given that satellite rainfall estimates are contaminated by sources such as temporal sampling, instrument and algorithm error (Gebremichael et al., 2005), it is important to assess the accuracy of these estimates. Table 1 summarizes recent studies on evaluations of three widely used SREs: Climate Prediction Center morphing method (CMORPH), Precipitation Estimation from Remotely Sensed Information Using Neural Networks (PERSIANN) and Tropical Rainfall Measuring Mission (TRMM) Multisatellite Precipitation Analysis (TMPA) 3B42.

The results of these studies indicate that the SREs performance varies with season, region and elevation. For instance, Gottschalck et al. (2005) evaluated the performance of PERSIANN and TMPA 3B42RT over the Continental United States (CONUS), and found the performance to be influenced by seasonal precipitation patterns. Their study found that both SREs overestimated precipitation over the central CONUS and western mountains during the spring and summer. However, during the fall and winter months PERSIANN underestimated precipitation in the western mountains and TMPA 3B42RT overestimated. Tian et al. (2007) furthered the work of Gottschalck et al. (2005) by evaluating CMORPH over the CONUS and found that there was an underestimation over the northeast during the summer months, but a severe overestimation over the central CONUS and mountain west during the summer and spring months. Zeweldi and Gebremichael (2008) evaluated CMORPH over Oklahoma and found there to be a positive bias during the summer months, but a negative bias during the winter months. 
Table 1. Evaluations on High Resolution Satellite Product.

\begin{tabular}{|c|c|c|c|}
\hline $\begin{array}{l}\text { Rainfall product } \\
\text { evaluated }\end{array}$ & Region & Main results & Reference \\
\hline $\begin{array}{l}\text { CMORPH } \\
\text { TMPA 3B42RT } \\
\text { TMPA 3B42 }\end{array}$ & $\begin{array}{l}\text { Western Highlands } \\
\text { Ethiopia, Africa }\end{array}$ & $\begin{array}{l}\text { Occurrence of rain underestimated by all products } \\
\text { Total amount underestimated by TMPA 3B42 }(14 \%) \text {; } \\
\text { overestimated by TMPA 3B42RT (13\%) and CMORPH }(11 \%)\end{array}$ & Dinku et al. (2010) \\
\hline $\begin{array}{l}\text { CMORPH } \\
\text { TMPA 3B42RT } \\
\text { TMPA 3B42 }\end{array}$ & $\begin{array}{l}\text { Highlands, Columbia, } \\
\text { South America }\end{array}$ & $\begin{array}{l}\text { Occurrence of rain underestimated by all products } \\
\text { Total amount underestimated by all products; TMPA } \\
\text { 3B42RT }(17 \%) \text {, TMPA 3B42 }(16 \%) \text { and CMORPH }(9 \%)\end{array}$ & Dinku et al. (2010) \\
\hline $\begin{array}{l}\text { CMORPH } \\
\text { PERSIANN } \\
\text { TMPA 3B42RT }\end{array}$ & $\begin{array}{l}\text { Great Rift Valley, } \\
\text { Ethiopia, Africa }\end{array}$ & $\begin{array}{l}\text { TMPA 3B42RT and CMORPH show elevation-dependent } \\
\text { trends, with underestimation at higher elevations } \\
\text { PERSIANN significantly underestimates at higher elevations. } \\
\text { Does not exhibit elevation-dependent trends }\end{array}$ & Hirpa et al. (2010) \\
\hline $\begin{array}{l}\text { CMORPH } \\
\text { PERSIANN- } \\
\text { CCS }\end{array}$ & $\begin{array}{l}\text { Berressa Watershed, } \\
\text { Ethiopia, Africa }\end{array}$ & $\begin{array}{l}\text { Both underestimate heavy rainfall by } 50 \% \\
\text { Both underestimate total rainfall; CMORPH (32\%), } \\
\text { PERSIANN-CCS ( } 49 \%)\end{array}$ & $\begin{array}{l}\text { Bitew and } \\
\text { Gebremichael (2009) }\end{array}$ \\
\hline $\begin{array}{l}\text { TMPA 3B42 V.6 } \\
\text { CMORPH }\end{array}$ & Mainland China, Asia & $\begin{array}{l}\text { Overestimate rainfall less than } 1 \mathrm{~mm} \mathrm{day}^{-1} \\
\text { Underestimate rainfall greater than } 1 \mathrm{~mm}^{-1} \text { day }^{-1} \text {. }\end{array}$ & Yu et al. (2009) \\
\hline CMORPH & $\begin{array}{l}\text { Oklahoma, United States, } \\
\text { North America }\end{array}$ & Positively biased in summer, negatively biased in winter & $\begin{array}{l}\text { Zeweldi and } \\
\text { Gebremichael (2008) }\end{array}$ \\
\hline $\begin{array}{l}\text { CMORPH } \\
\text { PERSIANN } \\
\text { TRMM 3B42 }\end{array}$ & $\begin{array}{l}\text { Sierra Madre Occidental, } \\
\text { Northwest Mexico, } \\
\text { North America }\end{array}$ & $\begin{array}{l}\text { CMORPH and PERSIANN overestimate the precipitation rate } \\
\text { and frequency. } \\
\text { TRMM 3B } 42 \text { closely agrees with the rain gauge network. }\end{array}$ & Nesbitt et al. (2008) \\
\hline TMPA 3B42 V.6 & $\begin{array}{l}\text { La Plata Basin, South } \\
\text { America }\end{array}$ & $\begin{array}{l}\text { Overestimation by } 3 \%-13 \% \text { for all sub basins assessed, } \\
\text { except one, which underestimated by } 1 \% \text {. }\end{array}$ & Su et al. (2008) \\
\hline $\begin{array}{l}\text { PERSIANN- } \\
\text { CCS }\end{array}$ & $\begin{array}{l}\text { Sierra Madre Occidental, } \\
\text { Northwest Mexico, } \\
\text { North America }\end{array}$ & $\begin{array}{l}\text { Overestimates precipitation at low elevations, underestimates } \\
\text { light precipitation at higher elevations; exhibits } \\
\text { elevation-dependant bias }\end{array}$ & Hong et al. (2007) \\
\hline $\begin{array}{l}\text { CMORPH } \\
\text { TMPA 3B42 V6 }\end{array}$ & $\begin{array}{l}\text { Continental United States } \\
\text { (CONUS), North } \\
\text { America }\end{array}$ & $\begin{array}{l}\text { TMPA 3B42 has near zero biases }\left(-1 \mathrm{~mm} \mathrm{day}^{-1} \text { to }\right. \\
\left.1 \mathrm{~mm} \mathrm{day}^{-1}\right) \text { for both summer and winter months. } \\
\text { CMORPH severely overestimates precipitation over central } \\
\text { CONUS; underestimates over the northeast during the summer. } \\
\text { Severe underestimation over western and north east during } \\
\text { winter months. }\end{array}$ & Tian et al. (2007) \\
\hline $\begin{array}{l}\text { PERSIANN } \\
\text { TMPA 3B42RT }\end{array}$ & $\begin{array}{l}\text { Continental United States } \\
\text { (CONUS), North } \\
\text { America }\end{array}$ & $\begin{array}{l}\text { PERSIANN overestimate total precipitation over central } \\
\text { CONUS and western mountains during spring and summer } \\
\text { months. Underestimation over central CONUS and mountain } \\
\text { west during fall and winter months. } \\
\text { TMPA 3B42RT overestimate total precipitation over central } \\
\text { CONUS and mountain west during spring and summer months. } \\
\text { Overestimation over western mountains during fall and winter. }\end{array}$ & Gottschalck et al. (2005) \\
\hline
\end{tabular}

The effect that topography has on the performance of SREs in particular is evidenced by several studies within Table 1 . Hong et al. (2007) evaluated the impact that topography might have on the performance of PERSIANN-Cloud Classification System (CCS) within the Sierra Madre Occidental (SMO) in western Mexico and found that the bias was affected by the topography. Their study showed that light precipitation events were underestimated in the high el- evations and that precipitation in the lower elevation were overestimated. Hirpa et al. (2010) performed an evaluation of CMORPH, PERSIANN and TMPA 3B42RT within the Awash River Basin of Ethiopia and found elevationdependent trends, with underestimation at higher elevation for CMORPH and TMPA 3B42RT. Bitew and Gebremichael (2009) evaluated the performance of CMORPH and PERSIANN-CCS in a small high elevation region of the 
Ethiopia Highlands and found that both underestimated total rainfall; CMORPH by $32 \%$ and PERSIANN-CCS by $49 \%$. These results bring to light the idea that evaluation studies of SREs must be region specific, and as indicated by Hong et al. (2007) and Hirpa et al. (2010), must take into consideration the elevation in addition to the specific region.

This study aims to evaluate the accuracy of three widely used SREs (CMORPH, PERSIANN and TMPA 3B42RT) across Ethiopia, focusing on smaller regions (river basins). Section 2 of this paper provides a brief discussion on the study regions and climate, along with a brief discussion on the rain gauge and SRE data. Section 3 presents the results (and discussion) of an intercomparison of the SREs through the spatial and seasonal patterns, as well as the performance of the SREs to the rain gauge data, which are not without error. This is especially true in mountainous regions, where the challenge for ground based rain gauges is that they are often difficult to physically locate or routinely maintain, making their distribution sparse. To address the spatial representativeness, and random errors, inherent in rain gauge data, the methodology consists of comparing the SREs to rain gauge data on long term (2003-2007) averages. The comparison to the rain gauge data is through the spatial pattern of the bias ratio, as well as an evaluation of the dependence of the bias ratio in the SREs on elevation. Conclusions are provided in Sect. 4.

\section{Study region and data}

\subsection{Study region}

The Great Rift Valley highlights the complex topography found within Ethiopia (Fig. 1), and splits the center of the country in the northeast and southwest direction by the divergence of tectonic plates. This prominent feature produces the Ethiopian Highlands, which are found on either side of the Great Rift Valley; the highest elevation along these highlands is in excess of $4200 \mathrm{~m}$. The topography on the southeast side of the highlands descends and levels off towards the border between Somalia and Ethiopia. The most mountainous terrain is found to the northwest of the Great Rift Valley and is highlighted by the Blue Nile River.

Figure 1 shows the ground based rain gauges, which will be further discussed in Sect. 2.3, that were available for conducting this study along with the six study regions. The Awash, Baro Akobo, Blue Nile, Genale Dawa, Rift Valley and Wabi Shebele River Basins were chosen based on a threshold of at least 10 rain gauges per river basin. These provide six unique study regions in terms of topography, seasonal precipitation and climate: the Baro Akobo and Blue Nile River Basins are located in the mountainous northwest, the Genale Dawa and Wabi Shebele River Basins are located within the dry and flat southeast, and the Awash and Rift Valley River Basins are located within the Rift Valley (see

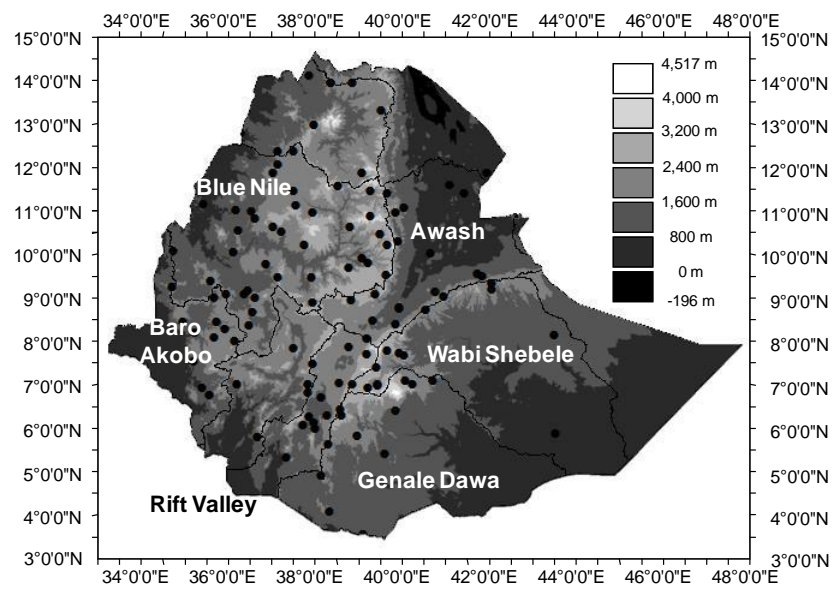

Fig. 1. Six river basins of Ethiopia evaluated and associated rain gauges.

Fig. 1). Table 2 provides drainage area (from Awulachew et al., 2007), the approximate elevation range for the river basin, as well as the elevation range for the rain gauges within the given river basin.

\subsection{Climate}

Ethiopia has three distinct seasons, each with differing precipitation totals. The Belg, approximately defined by March to the end of May, is considered the minor rainy season for most of the river basins, and is generated by weather systems that originate over the Indian Ocean (Seleshi and Zanke, 2004). The Kiremt, approximately defined by June to the end of September, is considered the major rainy season. The seasonal oscillation of the Intertropical Convergence Zone (ITCZ) is the predominant mechanism for the rainfall during the Kiremt (Seleshi and Zanke, 2004; Segele et al., 2008). The Bega is the dry season and is approximately defined by October through the end of February. This season was excluded from the analysis because of the overall low contribution to the mean annual precipitation.

Table 3 provides the mean annual precipitation for each of the river basins, along with the seasonal contribution delivered by the Belg and the Kiremt, as obtained from the average values of the three SREs.

The Baro Akobo and Blue Nile River Basins receive the highest precipitation totals at $1465 \mathrm{~mm}$ and $1305 \mathrm{~mm}$, respectively. The Kiremt contributes more than half of the annual precipitation to the Baro Akobo River Basin, and $75 \%$ to the Blue Nile River Basin.

Genale Dawa and Wabi Shebele River Basins, found in the southeast, receive the lowest precipitation totals of the six river basins assessed. Unlike the two aforementioned river basins, these two receive more than half of their precipitation during the Belg. The Kiremt provides the least amount 
Table 2. River basin drainage area and topography.

\begin{tabular}{|c|c|c|c|c|c|}
\hline \multirow{2}{*}{ River basin } & \multirow{2}{*}{$\begin{array}{r}\text { Drainage } \\
\text { area }\left(\mathrm{km}^{2}\right)\end{array}$} & \multicolumn{2}{|c|}{$\begin{array}{c}\text { Range of river } \\
\text { basin elevation (m) }\end{array}$} & \multicolumn{2}{|c|}{$\begin{array}{c}\text { Range of rain } \\
\text { gauge elevation }(\mathrm{m})\end{array}$} \\
\hline & & Min & Max & Min & Max \\
\hline Awash & 112,696 & 0 & 4,175 & 376 & 2,354 \\
\hline Baro Akobo & 75,912 & 400 & 3,220 & 1,460 & 2,310 \\
\hline Blue Nile & 199,812 & 480 & 4,250 & 902 & 3,040 \\
\hline Genale Dawa & 171,042 & 160 & 4,375 & 1,066 & 2,840 \\
\hline Rift Valley & 52,739 & 455 & 4,175 & 1,260 & 2,480 \\
\hline Wabi Shebele & 202,697 & 175 & 4,240 & 295 & 2,940 \\
\hline
\end{tabular}

Table 3. River basin precipitation characteristics

\begin{tabular}{|c|c|c|c|c|}
\hline \multirow{2}{*}{ River basin } & \multirow{2}{*}{$\begin{array}{l}\text { Number of } \\
\text { rain gauges }\end{array}$} & \multirow{2}{*}{$\begin{array}{r}\text { Mean annual } \\
\text { precipitation } \\
(\mathrm{mm})\end{array}$} & \multicolumn{2}{|c|}{ Seasonal contribution ${ }^{1}$} \\
\hline & & & Belg & Kiremt \\
\hline Awash & 16 & 585 & $28 \%$ & $66 \%$ \\
\hline Baro Akobo & 11 & 1,465 & $29 \%$ & $52 \%$ \\
\hline Blue Nile & 37 & 1,305 & $16 \%$ & $75 \%$ \\
\hline Genale Dawa & 11 & 340 & $56 \%$ & $12 \%$ \\
\hline Rift Valley & 12 & 650 & $47 \%$ & $29 \%$ \\
\hline Wabi Shebele & 13 & 365 & $51 \%$ & $31 \%$ \\
\hline
\end{tabular}

${ }^{1}$ Average of CMORPH, PERSIANN and TMPA 3B42RT estimates.

of precipitation for Genale Dawa, where as Wabi Shebele receives the least amount during the Bega.

The Awash and Rift Valley River Basins fall in the middle, when ranking the mean annual precipitation, with $585 \mathrm{~mm}$ and $650 \mathrm{~mm}$, respectively. The Kiremt delivers two-thirds of the precipitation to the Awash River Basin and the Belg delivers almost half of the annual precipitation to the Rift Valley River Basin.

\subsection{Rain gauge data}

Rain gauge data, provided by the Ethiopian Meteorological Agency (2003-2007), was available for 118 stations throughout Ethiopia. More than $75 \%$ of the rain gauges in any one basin are defined as a principle (or first class) rain gauge, which is one that has "observations taken by trained observers" (Dinku et al., 2008).

The temporal resolution of the provided rain gauge data was monthly and in assessing the rain gauges with recorded data between 2003 and 2007 it became apparent that there were missing months. More than $70 \%$ of the data was available during the 2003 to 2007 Belg for the six basins evaluated; only Genale Dawa and Awash had less than $70 \%$ of the data (69\% and $68 \%$, respectively) for the Kiremt. There was no attempt to fill in the missing data points, and if monthly data for a specific year was missing then it, along with the corresponding satellite data, was excluded from the study. The approach chosen was to assess the data using a five-year average, thereby minimizing the random errors in the data, making a qualitative assessment of the results possible (Hirpa et al., 2010).

Figure 1 shows that the location of the gauges provided varied spatial representation of the individual river basins. This is evident by comparing the distribution (and number of) gauges within each of the river basins. The Blue Nile, for example, is the most data rich of the river basins evaluated with 37 rain gauges scattered throughout the river basin that cover an elevation range of $2138 \mathrm{~m}$. The maximum elevation difference between any given rain gauge station within this river basin is $192 \mathrm{~m}$, with an average elevation difference of $63 \mathrm{~m}$. The 16 rain gauges within the Awash River Basin cover an elevation of $1978 \mathrm{~m}$. In stark contrast, the 11 rain gauges within the Baro Akobo River Basin cover an elevation range of only $850 \mathrm{~m}$, or only $30 \%$ of the total elevation range.

It is acknowledged here that rain gauges are merely point measurements and it is desired to have a densely populated network in order to compare them with satellite estimates. Although several of the river basins contain a network of rain gauges that represent a large majority of the elevation range within the given river basin, there is typically only one rain 

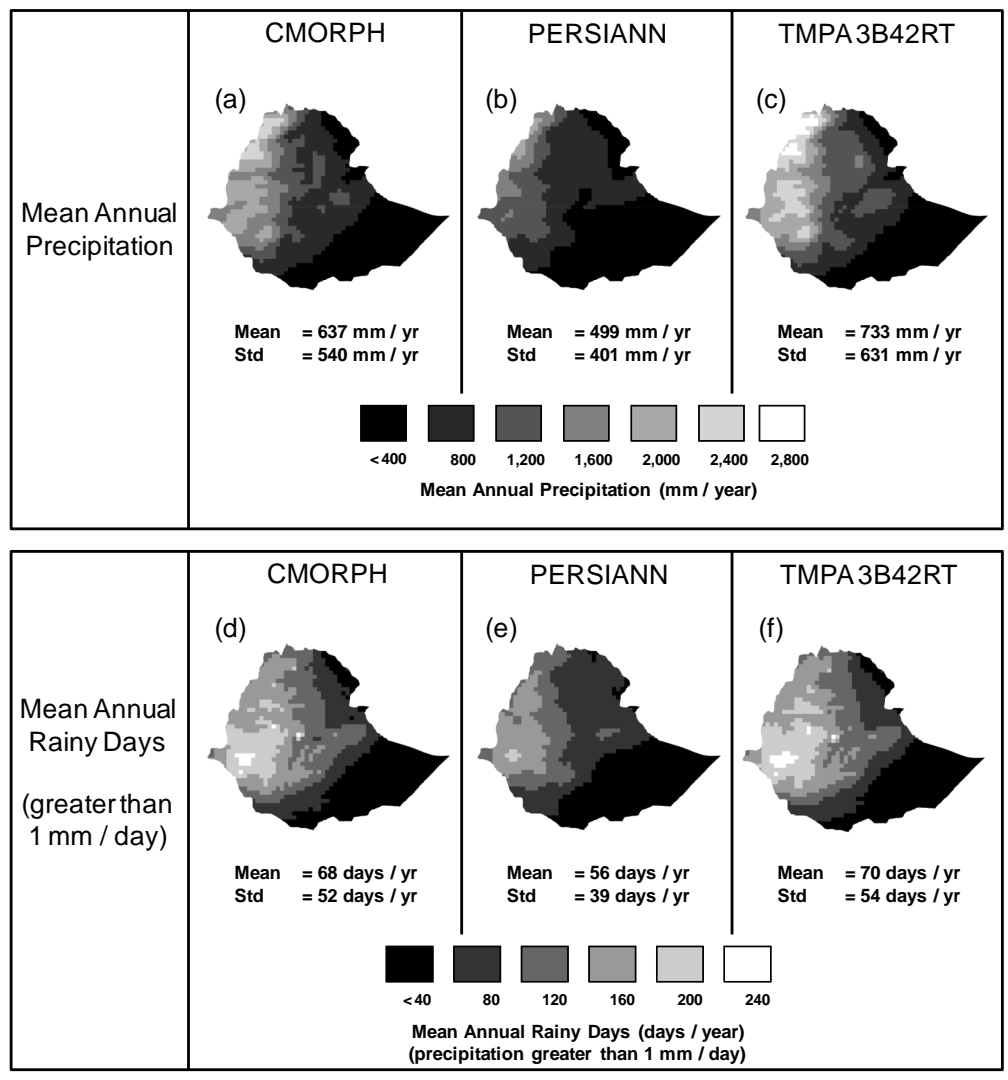

Fig. 2. (a-c) Mean annual precipitation $\left(\mathrm{mm} \mathrm{yr}^{-1}\right)$, (d-f) mean annual rainy days (precipitation greater than $\left.1 \mathrm{~mm} \mathrm{day}^{-1}\right)$.

gauge within a given $0.25^{\circ}$ by $0.25^{\circ}$ pixel for comparison with satellite data. However, by averaging the rain gauge observations over a five-year period, we have minimized the spatial representative error in the rain gauge estimates.

\subsection{Satellite data}

The three high resolution satellite products evaluated in this paper estimate precipitation at the same spatial $\left(0.25^{\circ}\right.$ by $0.25^{\circ}$ ) and temporal (3-hourly) resolution, but achieve the estimates using different means. The morphing method, developed by the Climate Prediction Center (CPC), estimates precipitation using only microwave (MW) data, however, due to the limited space-time resolution and the desire to generate data at a temporal resolution of 3-h, gaps in the MW data need to be estimated. In order to fill the gaps in the MW data, infrared (IR) data is used to generate motion vectors for which time weighted averages of the MW data are generated (Joyce et al., 2004). Precipitation Estimation from Remotely Sensed Information using Artificial Neural Networks (PERSIANN) was developed by the University of Arizona in 1997 to estimate rainfall by using IR data as input to artificial neural networks (ANNs), and when available, ground based data to update the ANNs (Hsu et al., 1997). The Tropical Rainfall Measuring Mission (TRMM) Multisatellite
Precipitation Analysis (TMPA) 3B42 Real Time (RT) product produces precipitation estimates by converting data from the TRMM Microwave Imager (TMI), Special Sensor Microwave/Sensor (SSM/I) and the real time data from the Advanced Microwave Scanning Radiometer for the Earth Orbiting System (AMSR-E) using the Goddard Profiling Algorithm (Kummerow et al., 1996; Olson et al., 1999). In order to provide 3-hourly precipitation estimates, IR data, which is calibrated using the TMI measurements, is used to fill in the gaps left by the MW data. Since this is the real time version of TMPA, calibration of the precipitation estimate using available rain gauges is not possible, therefore calibration is performed using the TMI sensor (Huffman et al., 2007).

When comparing the estimation methods between the three SREs used in this study, the major difference is in whether the estimate is generated using IR or MW data. The IR data, which is provided by geostationary satellites and therefore has better space-time coverage when compared to MW data, associates cloud top temperatures with specific rainfall intensities. MW data, which is provided by polar orbiting satellites, detects the liquid/ice scattering, and develops surface precipitation estimates through empirical relationships. 


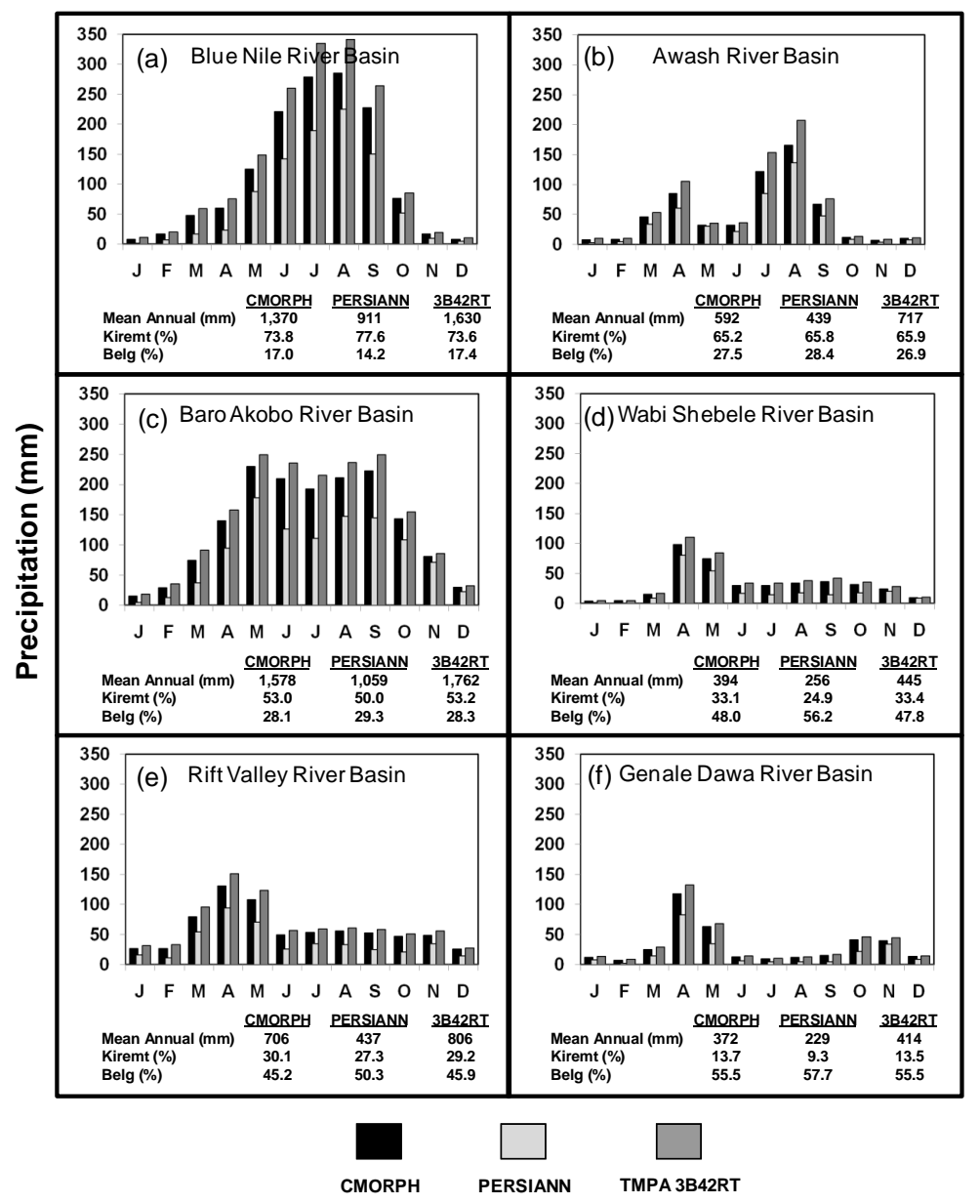

Fig. 3. Temporal precipitation pattern, 5 yr monthly average (2003-2007).

\section{Results}

\subsection{Spatial and seasonal precipitation patterns}

Figure 2 shows the spatial patterns of annual mean (20032007) rainfall and number of rainy days for Ethiopia, according to each SRE. All three SREs show a large northwestsoutheast gradient in both the mean annual rainfall and the number of rainy days. The northwest (Blue Nile) region receives mean annual rainfall up to $1630 \mathrm{~mm}$ according to TMPA 3B42RT (1370 mm and $911 \mathrm{~mm}$, according to CMORPH and PERSIANN, respectively), while the southeast (Genale Dawa and Wabi Shebele) region receives mean annual rainfall up to $429 \mathrm{~mm}$ according to TMPA 3B42RT (383 $\mathrm{mm}$ and $243 \mathrm{~mm}$, according to CMORPH and PERSIANN, respectively).

Figure 3 presents the basin-averaged monthly mean (2003-2007) rainfall for each river basin considered in this study, as derived from the SREs. The river basins show large variations in their seasonal rainfall patterns and total rainfall amounts. The Blue Nile River basin, located in the northwest, receives large amounts of rainfall (mean annual rainfall $=1370 \mathrm{~mm}$ from CMORPH, $911 \mathrm{~mm}$ from PERSIANN, $1630 \mathrm{~mm}$ from TMPA 3B42RT), with the vast majority $(74 \%$ to $78 \%$ ) falling in the Kiremt season (JuneSeptember), peaking in July and August. The Baro Akobo River basin, located in the west, also receives large amounts of rainfall (mean annual rainfall $=1578 \mathrm{~mm}$ from CMORPH, $1059 \mathrm{~mm}$ from PERSIANN, $1762 \mathrm{~mm}$ from TMPA 3B42RT) spread over most of the months, with Kiremt contributing half of the total rainfall. The Rift Valley River basin, located in southwest, receives a moderate amount of rainfall (mean annual rainfall $=706 \mathrm{~mm}$ from CMORPH, $437 \mathrm{~mm}$ from PERSIANN, $806 \mathrm{~mm}$ from TMPA 3B42RT), with more rain falling in the Belg season (March-May) and the rest evenly distributed across the rest of the months. The Awash River basin, located in the northeast, also receives a moderate amount of rainfall (mean annual rainfall $=592 \mathrm{~mm}$ from CMORPH, $439 \mathrm{~mm}$ from PERSIANN, $717 \mathrm{~mm}$ from TMPA $3 \mathrm{~B} 42 \mathrm{RT})$, with the vast majority falling in Kiremt $(\sim 65 \%)$ followed by Belg $(\sim 28 \%)$. The Wabi Shebele and Genale Dawa River basins, located in the southeast, receive the 
smallest rainfall amounts, with the majority falling in the Belg season. For all six river basins considered, the three SREs exhibit similar shapes of seasonal rainfall pattern, however, TMPA 3B42RT monthly rainfall estimates are consistently higher than $\mathrm{CMORPH}$, which are consistently higher than PERSIANN.

The study region can be divided into four regimes according to seasonal rainfall patterns and topography. The distinctive characteristics of the four regions are as follows:

1. The Northwest Region, consisting of the Blue Nile River basin. Its characteristics include highland topography, humid climate with mean annual rainfall of $1630 \mathrm{~mm}$ according to TMPA 3B42RT, and Kiremt as a major rainy season (contributes $\sim 75 \%$ of annual rainfall).

2. The South and Southeast Region, consisting of the Rift Valley, Wabi Shebele, and Genale Dawa River Basins. Its characteristics include lowland topography, semiarid climate with mean annual rainfall of $555 \mathrm{~mm}$ according to TMPA 3B42RT, and Belg as a major rainy season (contributes $45 \%$ to $55 \%$ of annual rainfall).

3. The Northeast Region, consisting of the Awash River basin. The Ethiopian rift system dissects this region into the highlands and lowlands. Its rainfall regime is the mix of the two rainfall regimes discussed above. Rainfall shows a clear bi-modal pattern.

4. The West Region, consisting of the Baro Akobo River basin. Its characteristics include highland topography, humid climate with mean annual rainfall of $1762 \mathrm{~mm}$ according to TMPA 3B42RT, and extended wet season over Belg, Kiremt, and parts of Bega.

\subsection{Dependence of bias ratio in SREs on elevation}

Our procedure of quantifying the bias ratio is as follows. First, we calculated the five-year seasonal mean rainfall at each rain gauge station based on the rain gauge data. Second, we extracted the $0.25^{\circ}$ by $0.25^{\circ} \mathrm{SRE}$ grid cells that contain rain gauges, and calculated the five-year seasonal mean rainfall at each grid cell based on the corresponding SRE data. Third, we calculated the bias ratio in the SREs at each grid cell through the bias ratio statistic, which is defined as the seasonal mean rainfall of SRE divided by the corresponding seasonal mean rainfall of rain gauge data. A bias ratio greater than one indicates overestimation by the SRE, a bias ratio less than one indicates underestimation by the SRE, and a bias ratio of one indicates no bias in the SRE (all with respect to the rain gauge data).

Let us first look at the spatial pattern of the bias ratio. Figure 4 presents the spatial pattern of the mean annual bias ratio (2003-2007) for the three SREs with the bias ratio presented

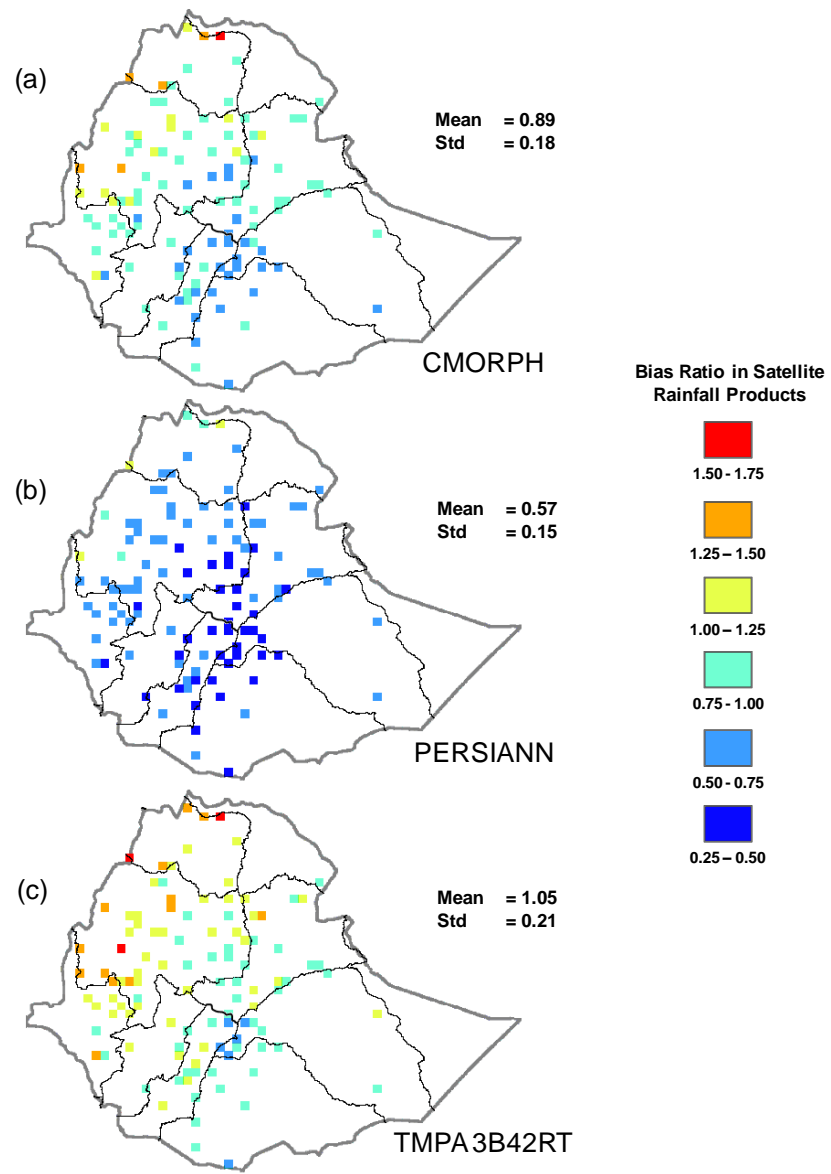

Fig. 4. Precipitation bias ratio in satellite rainfall products, $5 \mathrm{yr}$ average (2003-2007).

for each of the $0.25^{\circ}$ by $0.25^{\circ}$ grid cells that contain rain gauges. The country-averaged bias ratio is 1.05 for TMPA 3B42RT, 0.89 for CMORPH, and 0.57 for PERSIANN. So, PERSIANN results in severe underestimation of rainfall over Ethiopia.

Next, we examine the relationship between the bias ratio at each grid cell and the elevation of the grid cell, for different river basins and two rainy seasons. The bias ratios of the SREs as a function of elevation, for each river basin, are displayed in Fig. 5 for the Kiremt season, and in Fig. 6 for the Belg season. Also shown are the fitted lines with their slopes and correlation $(R)$ measuring the strength of the fitted lines. The dependence of the bias ratio on elevation depends on the SRE, region and season, as noted below:

In the northwest (Blue Nile River basin) region (elevation considered: $902 \mathrm{~m}$ to $3040 \mathrm{~m}$ ):

- During Kiremt, TMPA 3B42RT and CMORPH give reasonably accurate rainfall values over most of the elevations but substantially overestimate at some of the low-elevation areas. In contrast, during Belg, both products overestimate rainfall at low and medium-elevation 


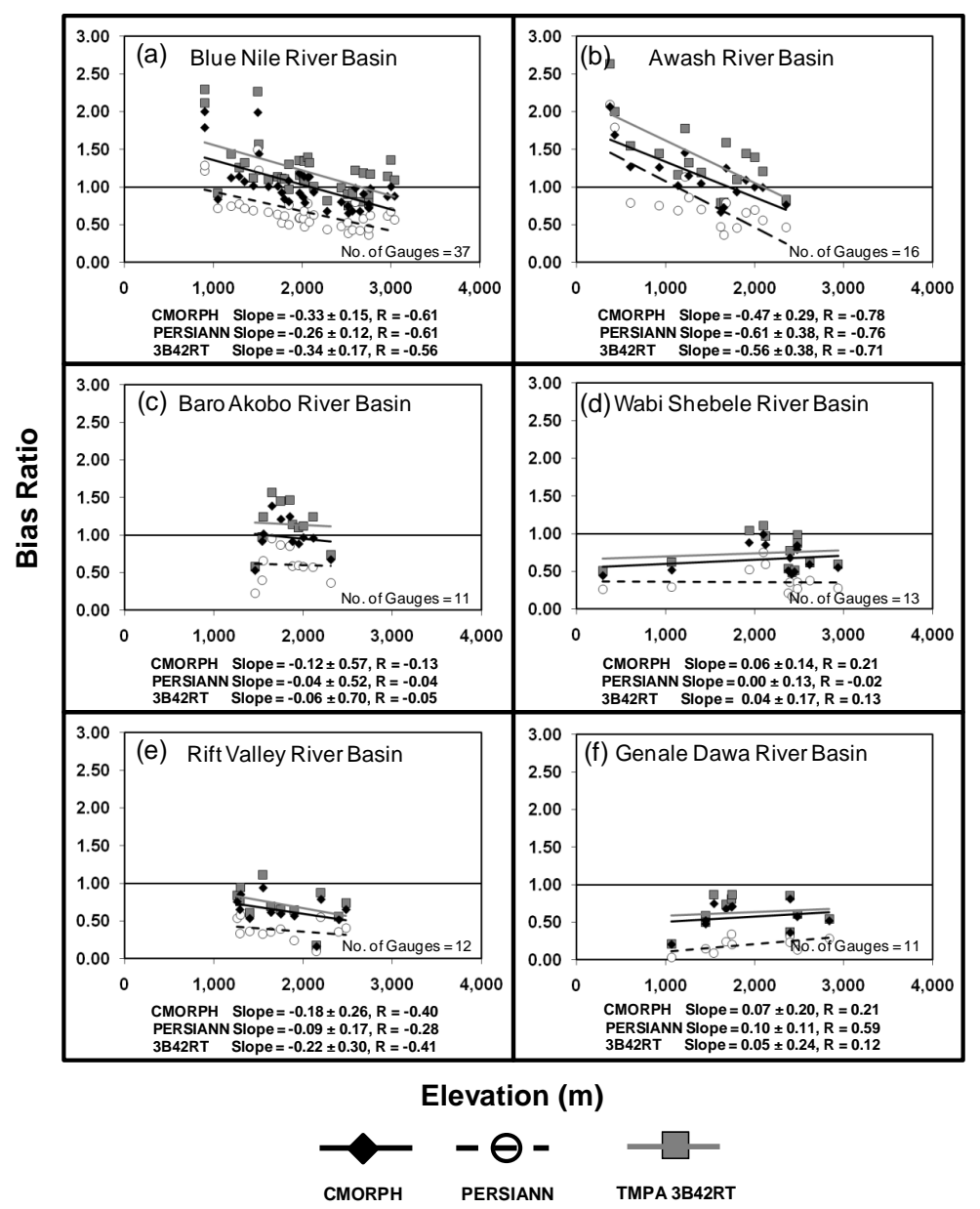

Fig. 5. Bias Ratio vs. Elevation for the Major Rainy Season (Kiremt).

areas but give reasonably accurate values at highelevation areas.

- During both Kiremt and Belg seasons, PERSIANN produces reasonably accurate rainfall values at lowelevation areas but substantially underestimates rainfall at high-elevation areas.

- The dependence of the bias ratio on elevation is stronger in the Belg season than in the Kiremt season, for all SREs.

In the northeast (Awash River basin) region (elevation considered: $376 \mathrm{~m}$ to $2354 \mathrm{~m}$ ):

- The behaviour of the bias ratio is similar with that for the northwest region

In the south and southeast (Rift Valley, Wabi Shebele, and Genale Dawa River Basins) region (elevation considered: $295 \mathrm{~m}$ to $2940 \mathrm{~m}$ ):

Hydrol. Earth Syst. Sci., 15, 1505-1514, 2011
- All SREs underestimate rainfall at most elevations in both Kiremt and Belg. PERSIANN gives the largest underestimation.

- No strong dependence of the bias ratio on elevation.

In the west (Baro Akobo River basin) region (elevation considered: $1460 \mathrm{~m}$ to $2310 \mathrm{~m}$ ):

- During Kiremt, TMPA 3B42RT overestimates, CMORPH gives reasonably accurate estimates, and PERSIANN underestimates. In contrast, during Belg, both TMPA 3B42RT and CMORPH overestimate while PERSIANN gives reasonably accurate values.

- No dependence of the bias ratio on elevation in both seasons.

\section{Discussion and conclusion}

Generally, the microwave-based products TMPA 3B42RT and CMORPH outperform the infrared-based product PERSIANN. On average, PERSIANN tends to underestimate 


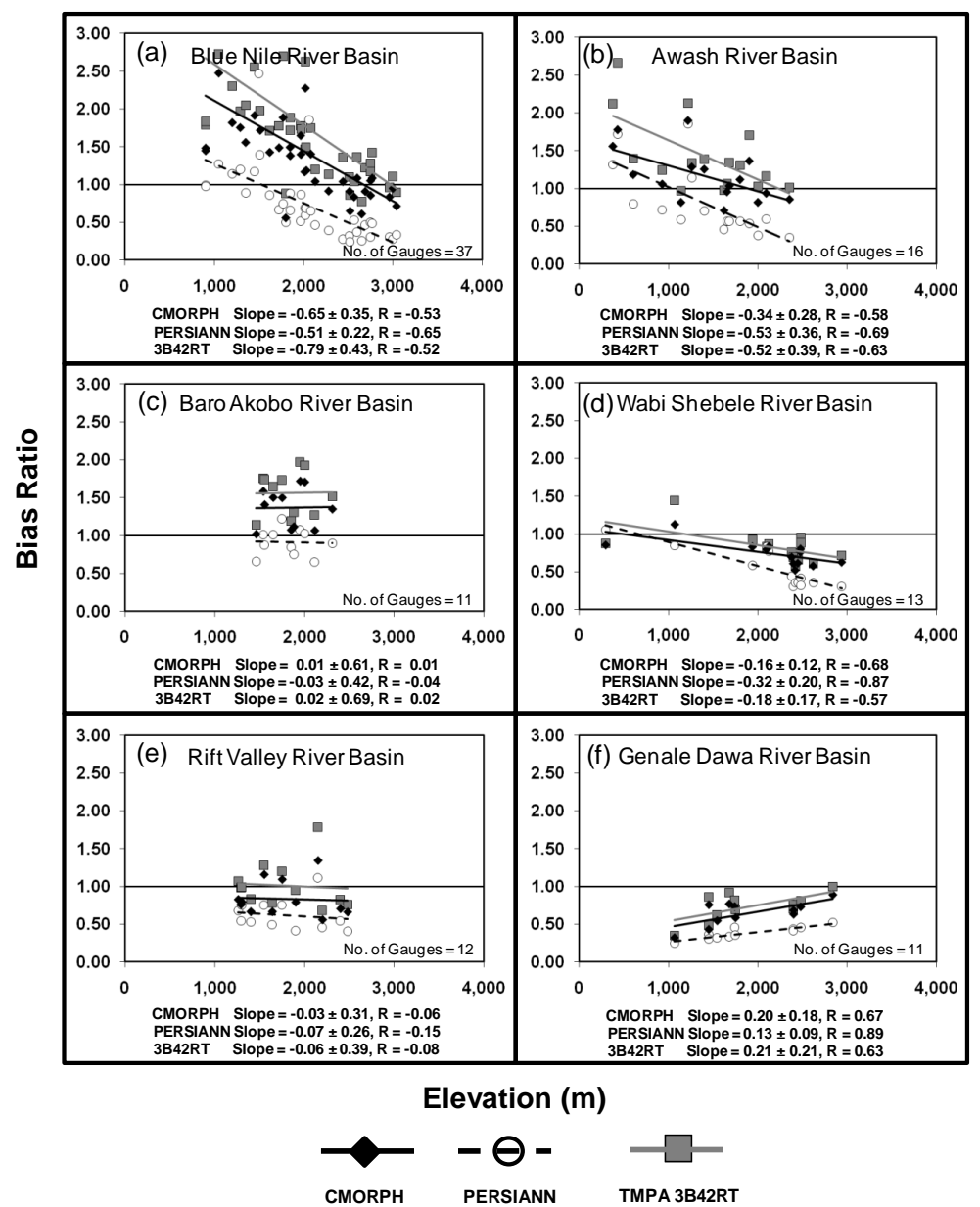

Fig. 6. Bias Ratio vs. Elevation for the Minor Rainy Season (Belg).

rainfall by $43 \%$, while CMORPH tends to underestimate by $11 \%$ and TMPA 3B42RT tends to overestimate by $5 \%$. The bias in the satellite rainfall estimates depends on the rainfall regime, and, in some cases, the elevation.

The northwest region (Blue Nile River basin) has a distinct rainfall regime, characterized by a strong ITCZ effect and highland topography. The ITCZ, which is the main rain producing mechanism during Kiremt, is centered to the North of Ethiopia and extends into the northwest region, the Blue Nile River basin (Segele et al., 2008). In this region, elevation influences the bias in the satellite rainfall estimates: TMPA 3B42RT and CMORPH tend to overestimate at low elevations but give reasonably accurate results at high elevations, whereas PERSIANN gives reasonably accurate values at low elevations but underestimates at high elevations. The overestimation by CMORPH and TMPA 3B42RT in the lowelevation areas of the Blue Nile basin may be associated with the deep convection of the ITCZ in the lower elevations leading to an increase in ice aloft, which is perceived by the MW sensors to be precipitation. The overestimation of precipita- tion by CMORPH within deep convective systems has been shown by Nesbitt et al. (2008). The improved performance of the CMORPH and TMPA 3B42RT in the high-elevation areas of the Blue Nile basin may be associated with the decreasing ice aloft. The reasonably accurate estimation of PERSIANN in the low-elevation areas of the Blue Nile basin may be due to the increased ice aloft bringing down the cold cloud temperature within the reasonably accurate range for the infrared rainfall algorithm. The poor underestimation by PERSIANN in the high-elevation areas of the Blue Nile basin may be due to the poor detection of the light rain events, consistent with the findings of Hong et al. (2007).

In the southeast region (Wabi Shebele, and Genale Dawa River Basins), which is characterized by lowland topography and strong southerly winds, elevation does not significantly influence the bias in the satellite rainfall estimates. In this region, all three satellite rainfall estimates underestimate rainfall at almost all elevations, which may be attributed to the southerly winds not producing sufficient ice aloft or having warmer cloud top temperatures. 
Acknowledgements. Support for this study came from two NASA Grants (Award \#: NNX08AR31G and NNX10AG77G) to the University of Connecticut.

Edited by: T. Steenhuis

\section{References}

Awulachew, S. B., Yilma, A. D., Loulseged, M., Loiskandl, W., Ayana, M., and Alamirew, T.: Water Resources and Irrigation Development in Ethiopia, Colombo, Sri Lanka: International Water Management Institute, 2007.

Bitew, M. M. and Gebremichael M.: Evaluation Through Independent Measurements: Complex Terrain and Humid Tropical Region in Ethiopia, in: Satellite Rainfall Applications for Surface Hydrology, edited by: Gebremichael, M. and Hossain, F., Springer Science+Business Media B.V., 2009.

Dinku, T., Chidzambwa, S., Ceccato, P., Connor, S. J., and Ropelewski, C. F.: Validation of high-resolution satellite rainfall products over complex terrain, Int. J. Remote Sens., 29(14), 4097-4110, doi:10.1080/01431160701772526, 2008.

Dinku, T., Connor, S. J., and Ceccato, P.:'Comparison of CMORPH and TRMM-3B42 over Mountainous Regions of Africa and South America, in: Satellite Rainfall Applications for Surface Hydrology, edited by: Gebremichael, M. and Hossaim, F., 193204. Springer Science+Business Media B.V., 2010.

Ethiopian Meteorological Agency, (EMA), Monthly Rain Gauge Data (2003 to 2007), Addis Ababa, Ethiopia, 2003-2007.

Gebremichael, M., Krajewski, W. F., Morrissey, M., Huffman, G., and Adler, R.: A detailed evaluation of GPCP one-degree daily rainfall estimates over the Mississippi River Basin, J. Appl. Meteorol., 44(5), 665-681, 2005.

Gottschalck, J., Meng, J., Rodell, M., and Houser, P.: Analysis of Multiple Precipitation Products and Preliminary Assessment of Their Impact on Global Land Data Assimilation System Land Surface States, J. Hydrometeorol., 6(5), 573-598, 2005.

Hirpa, F. A., Gebremichael, M., and Hopson, T.: Evaluation of High Resolution Satellite Precipitation Products over Very Complex Terrain in Ethiopia, J. Appl. Meteorol. Clim. - IPWG Special Collection, 49(5), 1044-1051, doi:10.1175/2009JAMC2298.1, 2010.

Hong, Y., Gochis, D., Cheng, J., Hsu, K., and Sorooshian, S.: Evaluation of PERSIANN-CCS Rainfall Measurement Using the NAME Event Rain Gauge Network, Journal of Hydrometeorology, 8(3), 469-482, doi:10.1175/JHM574.1, 2007.

Hsu, K., Gao, X., Sorooshian, S., and Gupta, H. V.: Precipitation Estimation from Remotely Sensed Information Using Artificial Neural Networks, J. Appl. Meteorol., 36(9), 1176-1190, 1997.

Huffman, G. J., Adler, R. F., Bolvin, D. T., Gu, G., Nelkin, E. J., Bowman, K. P., Hong, Y., Stocker, E. F., and Wolff, D. B.: The TRMM Multisatellite Precipitation Analysis (TMPA): Quasi-Global, Multiyear, Combined-Sensor Precipitation Estimates at Fine Scales, J. Hydromteorol., 8(1), 38-55, doi:10.1175/JHM560.1, 2007.

Joyce, R. J., Janowiak, J. E., Arkin, P. A., and Xie, P.: CMORPH: A Method that Produces Global Precipitation Estimates from Passive Microwave and Infrared Data at High Spatial and Temporal Resolution, J. Hydrometeorol., 5(3), 487-503, 2004.
Kummerow, C., Olson, W. S., and Giglio, L.: A Simplified Scheme for Obtaining Precipitation and Vertical Hydrometeor Profiles from Passive Microwave Sensors, IEEE T. Geosci. Remote, 34(5), 1213-1232, doi:10.1109/36.536538, 1996

Nesbitt, S. W., Gochis, D. J., and Lang, T. J.: The Diurnal Cycle of Clouds and Precipitation along the Sierra Madre Occidental Observed during NAME-2004: Implications for Warm Season Precipitation Estimation in Complex Terrain, J. Hydrometeorol., 9(4), 728-743, doi:10.1175/2008JHM939.1, 2008.

Olson, W. S., Kummerow, C. D., Hong, Y., and Tao, W. K.: Atmospheric Latent Heating Distributions in the Tropics Derived from Satellite Passive Microwave Radiometer Measurements, J. Appl. Meteorol., 38(6), 633-664, 1999.

Segele, Z. T., Lamb, P. J., and Leslie, L. M.: Large-scale atmospheric circulation and global sea surface temperature associations with Horn of Africa June-September rainfall, Int. J. Climatol., 29(8), 1075-1100, doi:10.1002/joc.1751, 2008.

Seleshi, Y. and Zanke, U.: Recent Changes in Rainfall and Rainy Days in Ethiopia, Int. J. Climatol., 24(8), 973-983, doi:10.1002/joc.1052, 2004.

Su, F., Hong, Y., and Lettenmaier, D. P.: Evaluation of TRMM Multisatellite Precipitation Analysis (TMPA) and Its Utility in Hydrologic Prediction in the La Plata Basin, J. Hydrometeorol., 9(4), 622-640, doi:10.1175/2007JHM944.1, 2008.

Tian, Y., Lidard-Peters, C. D., Choudhury, B. J., and Garcia, M.: Multitemporal Analysis of TRMM-Based Satellite Precipitation Products for Land Data Assimilation Applications, J. Hydrometeorol., 8(6), 1165-1183, doi:10.1175/2007JHM859.1, 2007.

Yu, Z., Yu, H., and Chen, P.: Verification of Tropical Cyclone-Related Satellite Precipitation Estimates in Mainland China, J. Appl. Meteorol. Clim., 48(11), 2227-2241, doi:10.1175/2009JAMC2143.1, 2009.

Zeweldi, D. A. and Gebremichael, M.: Evalutation of CMORPH Precipitation Products at Fine Space-Time Scales, J. Hydrometeorol., 10(1), 300-307, doi:10.1175/2008JHM1041.1, 2008. 